DOI: $10.29303 /$ jrpb.v9i2.272

ISSN 2301-8119, e-ISSN 2443-1354

Tersedia online di http://jrpb.unram.ac.id/

\title{
PENGUJIAN KAPASITAS KERJA APLIKATOR PUPUK ORGANIK TIPE SABUK BERJALAN PADA SAWAH TADAH HUJAN
}

\author{
Performance Test of Organic Fertilizer Applicator Belt Conveyor Type \\ on Rainfed Rice Field
}

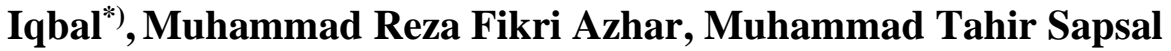

Program Studi Keteknikan Pertanian Fakultas Pertanian Universitas Hasanuddin Jl. Perintis Kemerdekaan km 10 kampus UNHAS Tamalanrea, Makassar, Sul-Sel, Indonesia

\author{
Email $^{*}$ ): iqbaliqma@yahoo.com
}

Diterima: Juli 2021

Disetujui: September 2021

\begin{abstract}
Soil nutrients have an important role in increasing plant productivity. It is makes farmers must use various types of fertilizers with the function of providing adequate nutrition and nutrients needed for plant growth. The application of organic fertilizers to agricultural land requires a lot of power and costs, especially if the land is large. To overcome this problem, an organic fertilizer applicator is used. This organic fertilizer applicator is then coupled with a twowheeled tractor as the tow. The aims of the research are to determine the working capacity and efficiency of the applicator use in rainfed rice fields. The research was conducted by using experimental methods in the field and analyzed descriptively. This applicator test uses three speed treatments, namely at $2.71 \mathrm{~km} / \mathrm{hour}, 3.38 \mathrm{~km} / \mathrm{hour}$ and $4.62 \mathrm{~km} / \mathrm{hour}$. The research carried out aims to determine the working capacity and efficiency of the applicator use in rainfed rice fields. The research was conducted by using experimental methods in the field and analyzed descriptively. This applicator test uses three speed treatments, namely at 2.71 $\mathrm{km} / \mathrm{hour}, 3.38 \mathrm{~km} / \mathrm{hour}$ and $4.62 \mathrm{~km} / \mathrm{hour}$. The plot size used for each speed is $45 \mathrm{~m} \times 27 \mathrm{~m}$. The measurement and calculation results show that a good applicator speed in rainfed rice fields is $2.71 \mathrm{~km} / \mathrm{hour}$. The work capacity obtained is 0.35 ha/hour for the theoretical field capacity. Meanwhile, the effective field capacity is 0.26 ha/hour. From the two work capacities, the field efficiency is $74.74 \%$.
\end{abstract}

Keywords: applicator; efficiency; work capacity; organic fertilizer; rainfed rice field

\begin{abstract}
ABSTRAK
Unsur hara tanah memiliki peran penting dalam peningkatan produktivitas tanaman. Hal ini yang kemudian membuat petani harus menggunakan berbagai jenis pupuk dengan fungsi memberikan kecukupan nutrisi serta unsur hara yang dibutuhkan dalam pertumbuhan tanaman. Pengaplikasian pupuk organik pada lahan pertanian membutuhkan tenaga dan biaya yang
\end{abstract}


besar, apalagi kalau lahan tersebut luas. Untuk mengatasi hal tersebut maka digunakan aplikator pupuk organik. Aplikator pupuk organik ini kemudian digandeng dengan menggunakan traktor roda dua sebagai penariknya. Penelitian yang dilakukan bertujuan untuk menentukan kapasitas kerja dan efisiensi penggunaan aplikator pada sawah tadah hujan. Penelitian dilakukan dengan metode percobaan di lapangan dan dianalisis deskriptif. Pengujian aplikator ini menggunakan tiga perlakuan kecepatan, yaitu pada $2,71 \mathrm{~km} / \mathrm{jam}, 3,38 \mathrm{~km} / \mathrm{jam}$ dan $4,62 \mathrm{~km} / \mathrm{jam}$. Ukuran petakan yang digunakan untuk masing-masing kecepatan adalah $45 \mathrm{~m} \mathrm{x}$ $27 \mathrm{~m}$. Hasil pengukuran dan perhitungan diperoleh bahwa kecepatan aplikator yang baik pada lahan sawah tadah hujan adalah $2,71 \mathrm{~km} / \mathrm{jam}$. Kapasitas kerja yang diperoleh adalah 0,35 ha/jam untuk kapasitas lapang teoritis. Sedangkan untuk kapasitas lapang efektif adalah 0,26 ha/jam. Dari kedua kapasitas kerja tersebut diperoleh efisiensi lapang 74,74\%.

Kata Kunci: aplikator; efisiensi; kapasitas kerja; pupuk organik; sawah tadah hujan

\section{PENDAHULUAN}

\section{Latar Belakang}

Indonesia memiliki lahan pertanian yang sangat luas dengan berbagai macam masalah. Pemerintah Indonesia diharapkan dapat melakukan pembenahan dan pengembangan sektor pertanian. Ini bertujuan meningkatkan produksi pertanian, khususnya tanaman padi sebagai sumber makanan pokok (Iqbal, et al., 2021). Masalah-masalah tersebut menghambat peningkatan produktivitas hasil pertanian khususnya padi sebagai komoditi utama masyarakat Indonesia. Salah satu yang menjadi masalah ialah minimnya kandungan nutrisi dan unsur hara di dalam tanah. Hasil penelitian Iqbal, et al. (2019), menunjukkan kandungan bahan organik tanah dapat mempengaruhi kemampuan tanah untuk mengikat air dan mengefisiensikan penyerapan pupuk oleh akar tanaman serta sebagai nutrisi penting bagi pertumbuhan tanaman. Karenanya, penambahan bahan organik sangat penting untuk menjaga produktivitas lahan pertanian. Unsur hara memiliki peran dalam pertumbuhan dan perkembangan tanaman, khususnya pada tanaman padi. Hal inilah yang kemudian membuat petani harus menggunakan berbagai jenis pupuk dengan fungsi memeberikan kecukupan nutrisi yang dibutuhkan tanaman dalam pertumbuhannya.
Ada dua jenis pupuk, yakni pupuk anorganik dan pupuk organik. Dewanto, et al. (2017), mengungkapkan bahwa pupuk anorganik dibuat dengan melalui serangkaian proses kimia, fisik maupun biologis yang biasanya diproduksi oleh industri pembuatan pupuk. Sementara itu, pupuk organik terbuat dari bahan-bahan organik dari hewan maupun tumbuhan yang mengalami proses pembuatan atau rekayasa. Pupuk organik biasanya berbentuk padat maupun bentuk cair.

Hasil penelitian Sri \& Soepartini (1995) menunjukkan bahwa dengan melakukan praktek pemupukan dengan pupuk kimia secara tidak berimbang, di samping tidak efisien, hal ini akan mengganggu kesetimbangan kandungan hara di dalam tanah serta kelestarian lingkungan. Dampak lain juga disebutkan oleh Reijntjes \& Haverkort (1999) adalah menurunnya efisiensi proses pemupukan, kehidupan mikzroorganisme akan terganggu di dalam tanah, struktur tanah akan terdegradasi sehingga mudah mengalami kekeringan, dan akan menipiskan jumlah unsur hara mikro. Hal tersebut mengindikasikan perlunya dilakukan peralihan penggunaan pupuk anorganik ke pupuk organik.

Pada pengaplikasiannya, penyebaran pupuk di lahan pertanian membutuhkan tenaga dan biaya yang cukup besar, terlebih jika lahan tersebut cukup luas. Untuk 
mengatasi hal tersebut, maka digunakanlah aplikator untuk mengurangi biaya dan tenaga serta mengefektifkan waktu proses pemupukan. Aplikator ini dirancang khusus untuk menyebarkan bahan/pupuk organik ke lahan pertanian dengan dosis tertentu. Aplikator pupuk organik ini kemudian digandeng dengan menggunakan traktor roda dua sebagai penariknya.

Alat aplikasi pupuk organik ini berupa trailer yang terdiri dari, auger penyalur, lubang tempat keluarnya kompos, pintu pengatur jumlah keluarnya kompos, belt conveyor sebagai metering device, pembuka alur dan kotak pupuk serta rangka utama alat. Alat ini akan beroperasi dengan cara digandeng oleh traktor penarik

Pada penelitian sebelumnya, telah dilakukan pengujian aplikator pupuk organik untuk tebu lahan kering oleh Iqbal (2014). Hasil penelitian tersebut, menyatakan bahwa penggunaan dari aplikator yang dilengkapi penjatah tipe sabuk berjalan dapat berfungsi dengan baik dan diperoleh efisensi sebesar $54 \%$.

Penelitian lainnya yang dilakukan Hartono, et al. (2018) dengan melakukan modifikasi aplikator kompos tanaman tebu lahan kering untuk digunakan di lahan tanaman hortikultura dengan menggunakan tenaga tarik traktor roda dua (traktor tangan). Hasil yang diperoleh adalah aplikator pupuk organik untuk tanaman hortikultura menggunakan penjatah tipe belt conveyor dapat berfungsi dengan baik. Aplikator yang dibuat dapat mengangkut kompos sebesar $1 \mathrm{~m}^{3}$. Hasil uji kinerja aplikator pupuk organik memiliki kapasitas lapang efektif sebesar $10 \mathrm{jam} / \mathrm{ha}$ dan kapasitas lapang teoritis sebesar $6,1 \mathrm{jam} / \mathrm{ha}$ sehingga diperoleh efisiensi kerja alat sebesar $61,7 \%$.

Penelitian pengoperasian aplikator pupuk organik menggunakan bahan organik berupa blotong di lahan sawah tadah hujan di Indonesia belum banyak dilakukan. Hal ini menjadi latar belakang mengapa penelitian ini perlu dilakukan.

\section{Tujuan Penelitian}

Tujuan penelitian ini yaitu untuk menentukan dan menghitung kapasitas kerja dan efisiensi aplikator pupuk organik pada lahan sawah tadah hujan.

\section{METODE PENELITIAN}

\begin{abstract}
Alat dan Bahan
Digunakan beberapa peralatan dalam penelitian ini antara lain: aplikator pupuk organik tipe belt conveyor, traktor roda dua, meteran, timbangan, dan patok. Bahan organik blotong merupakan bahan yang digunakan dalam penelitian ini.
\end{abstract}

\section{Prosedur Penelitian}

Persiapan

Persiapan yaitu hal-hal yang dipersiapkan sebelum melakukan pengambilan data yakni observasi lahan yang akan digunakan, pengecekan alat dan bahan teknis yang mendukung pengujian alat.

Pelaksanaan

Penelitian ini dilakukan dengan mengikuti bagan alir seperti pada Gambar 1 .

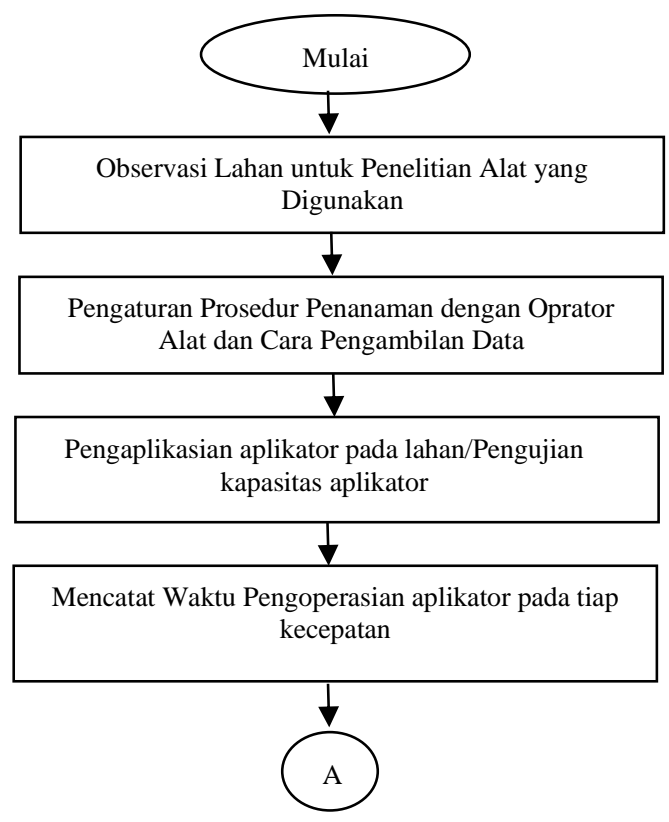




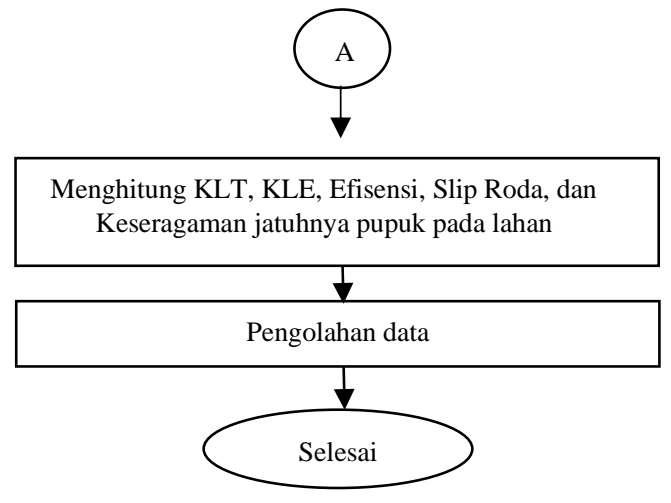

Gambar 1. Bagan Alir Penelitian

Persamaan yang digunakan

1. Perhitungan kapasitas lapang teoritis (Permatasari, 2014)

$$
K L T=W * V
$$

Dimana:

$\mathrm{V} \quad=$ Kecepatan $(\mathrm{m} / \mathrm{jam})$

$\mathrm{W} \quad=$ Lebar kerja alat $(\mathrm{m})$

KLT = Kapasitas lapang teoritis (ha/jam)

2. Menentukan kapasitas lapang efektif (Permatasari, 2014)

$$
K L T=\frac{L}{T} .
$$

Dimana:

$\mathrm{T}=$ Total waktu tempuh (jam)

$\mathrm{L} \quad=$ Luas Lahan $\left(\mathrm{m}^{2}\right)$

KLE $=$ Kapasitas lapang efektif (ha/jam)

3. Menentukan efisiensi (Permatasari, 2014)

$$
\text { Ef isiensi }=\frac{K L E}{K L T} * 100
$$

Dimana:

KLT = Kapasitas lapang teoritis (ha/jam)

KLE = Kapasitas lapang efektif (ha/jam)

\section{HASIL DAN PEMBAHASAN}

\section{Kondisi Lahan}

Penelitian dilakukan di sawah tadah hujan bertempat di Desa Parangbaddo, Kabupaten Takalar. Lahan ini berada di pinggir jalan desa yang di sekitarnya terdapat perkebunan tebu milik PTPN XIV Takalar. Dalam penggunaannya, lahan ini sering digunakan untuk menanam tanaman padi. Adapun pada saat dilakukannya pengujian, lahan tersebut memiliki nilai kadar air sebesar 5,08\%.

\section{Bahan Organik}

Blotong merupakan bahan organik yang digunakan pada penelitian ini. Blotong adalah endapan air perasan tebu (nira) pada proses pembuatan gula pasir. Sebelum aplikasi, blotong terlebih dulu dijemur untuk menghilangkan sebagian kadar air sehingga tidak menghambat putaran auger dan juga dapat menghalangi proses penyaluran pupuk organik (blotong). Pengaplikasian blotong dalam keadaan basah dapat menyebabkan melengketnya blotong pada auger.

\section{Kapasitas Lapang}

Penelitian ini menggunakan aplikator pupuk organik tipe belt conveyor yang ditarik oleh traktor roda 2 sebagai tenaga penggeraknya. Sabuk berjalan (belt conveyor) yang berfungsi sebagai penjatah bergerak menggunakan tenaga yang berasal dari putaran roda aplikator. Pergerakan roda yang berputar, bergerak maju akan menyebabkan konveyor sabuk bergerak maju untuk menjatah pupuk organik. Aplikator ini didesain khusus untuk menyalurkan pupuk organik ke tanah yang terdiri atas batang besi penggandeng, lubang pengeluaran, pengatur dosis (metering device), auger, dan penampung pupuk serta rangka utama (chasis) alat (Salim, 2012).

Tabel 1. Hasil Pengujian Aplikator

\begin{tabular}{cccc}
\multirow{2}{*}{ Perhitungan } & \multirow{3}{*}{ Satuan } & \multicolumn{2}{c}{ Kecepatan $(\mathrm{km} / \mathrm{jam})$} \\
& 2,71 & 3,38 & 4,62 \\
\hline
\end{tabular}

Kapasitas

Lapang ha/jam $\quad 0,35 \quad 0,44 \quad 0,6$

Teoritis/KLT

Kapasitas

Lapang ha/jam $\quad 0,26 \quad 0,32 \quad 0,43$

Efektif/KLE 
$\begin{array}{lllll}\text { Efisiensi } \quad \% & 74,74 & 73,4 & 71,67\end{array}$

Hasil pengukuran di lapang menunjukkan bahwa lebar kerja teoritis aplikator pupuk organik tipe belt conveyor adalah 1,3 m. Pengujian aplikator dilakukan pada lahan penelitian dengan panjang lintasan $45 \mathrm{~m}$ dengan tiga kecepatan berbeda yang kemudian diulangi sebanyak tiga kali dan diperoleh data bahwa waktu rata-rata aplikator untuk menyelesaikan satu lintasan pada kecepatan rendah yakni 60 detik, pada kecepatan sedang yakni selama 48 detik, dan pada kecepatan tinggi selama 35 detik. Sehingga rata-rata kecepatan maju aplikator pada kecepatan rendah yaitu $2,71 \mathrm{~km} / \mathrm{jam}$, pada kecepatan sedang yaitu $3,38 \mathrm{~km} / \mathrm{jam}$, dan pada kecepatan tinggi yaitu 4,62 $\mathrm{km} / \mathrm{jam}$. Adapun waktu total setiap satu kali pengujian pada lahan seluas $117 \mathrm{~m}^{2}$ adalah 0,044 jam untuk 2,71 km/jam; 0,036 jam pada kecepatan $3,38 \mathrm{~km} / \mathrm{jam}$; dan $0,027 \mathrm{jam}$ untuk kecepatan 4,62 km/jam.

\section{Kapasitas Lapang Teoritis (KLT)}

Pengujian ini dilakukan untuk mengetahui kemampuan kerja aplikator pada sebuah lahan. Perhitungan kapasitas lapang ini bertujuan untuk menghitung waktu kerja alat pada saat alat bekerja sempurna tanpa ada waktu terbuang seperti waktu belok atau waktu berhenti. Adapun perbandingan antara kecepatan dan kapasitas lapang teoritis alat dapat dilihat pada Gambar 2.

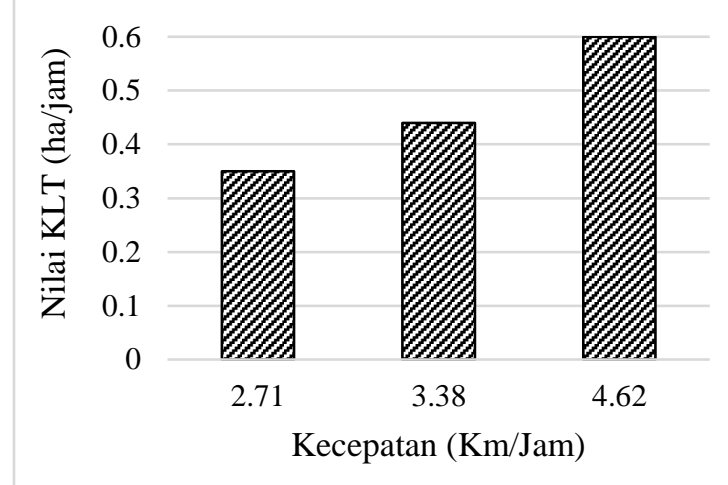

Gambar 2. Grafik Perbandingan Kecepatan dan Kapasitas Lapang Teoritis

Pada perlakuan kecepan 2,71 km/jam diperoleh hasil perhitungan Kapasitas Lapang Teoritis (KLT) sebesar 0,35 ha/jam atau sama dengan 2,83 jam/ha. Untuk perlakuan kecepatan 3,38 km/jam diperoleh KLT senilai 0,44 ha/jam atau sama dengan 2,27 jam/ha, dan pada perlakuan kecepatan 4,62 $\mathrm{km} / \mathrm{jam}$ diperoleh KLT senilai 0,6 ha/jam atau sama dengan 1,66 jam/ha. Berdasarkan hasil tersebut dapat diketahui bahwa untuk mengaplikasikan pupuk organik pada areal sawah 1 ha dengan menggunakan aplikator pupuk organik tipe sabuk berjalan (belt conveyor) membutuhkan waktu selama 2-3 jam. Data tersebut tidak jauh berbeda dengan hasil panelitian yang telah dilakukan oleh Hartono, et al. (2018), yang melakukan pengujian aplikator pupuk organik dengan tipe yang sama pada lahan tanaman melon dengan kecepatan 2,18 km/jam dan panjang lintasan $20 \mathrm{~m}$, dimana hasil perhitungan yang dilakukan diperoleh nilai KLT sebesar $0,28 \mathrm{ha} / \mathrm{jam}$.

\section{Kapasitas Lapang Efektif (KLE)}

Kapasitas lapang efektif dihitung dengan tujuan untuk mengetahui berapa waktu yang dibutuhkan aplikator pupuk organik tipe sabuk berjalan (belt conveyor) untuk mengaplikasikan pupuk pada lahan tertentu, yang dalam penelitian ini luas lahan yang digunakan yakni seluas $117 \mathrm{~m}^{2}$. 
Adapun hasil perhitungan KLE, terlihat pada Gambar 3.

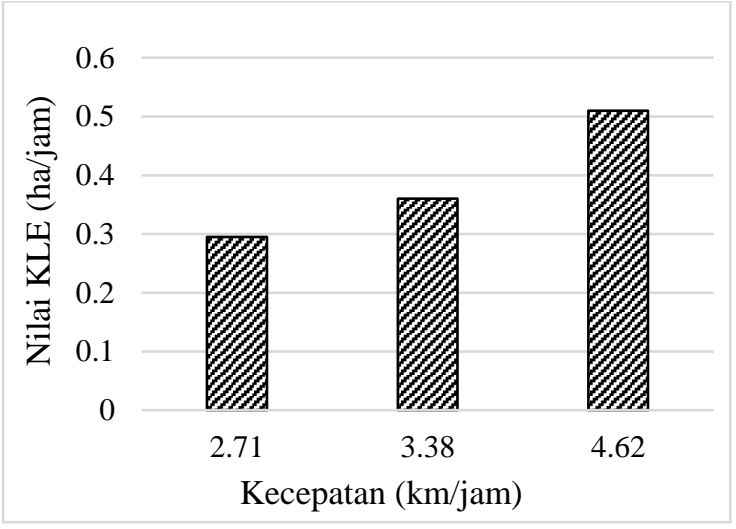

Gambar 3. Grafik Perbandingan Kecepatan dan Kapasitas Lapang Efektif

Hasil perhitungan KLE untuk kecepatan 2,71 km/jam sebesar 0,2945 ha/jam atau sama dengan 3,39 jam/ha. KLE untuk perlakuan kecepatan 3,38 km/jam diperoleh sebesar 0,36 ha/jam atau sama dengan $2,73 \mathrm{jam} / \mathrm{ha}$, dan pada perlakuan kecepatan 4,62 km/jam diperoleh nilai sebesar 0,51 ha/jam atau sama dengan 1,93 jam/ha. Berdasarkan data tersebut, maka waktu efektif yang dibutuhkan aplikator untuk menyelesaikan 1 ha lahan sawah yaitu selama 2 sampai 3 jam.

Data tersebut tidak jauh berbeda dengan hasil panelitian yang telah dilakukan oleh Hartono, et al. (2018), yang melakukan pengujian aplikator pupuk organik dengan tipe yang sama pada lahan tanaman melon dengan kecepatan $2,18 \mathrm{~km} / \mathrm{jam}$ dan luas lahan 72,8 dimana hasil perhitungan yang dilakukan diperoleh nilai KLE sebesar 0,24 $\mathrm{ha} / \mathrm{jam}$ atau setara $4,16 \mathrm{jam} / \mathrm{ha}$.

Adapun dalam memenuhi kebutuhan pupuk organik sebanyak 10 ton/hektar, pada kecepatan $2,71 \mathrm{~km} / \mathrm{jam}$ dibutuhkan waktu kerja efektif selama 8,87 jam, untuk kecepatan 3,38 km/jam dibutuhkan waktu kerja efektif selama 7,24 jam, dan untuk kecepatan 4,62 km/jam dibutuhkan waktu kerja efektif selama 5,42 jam untuk mengaplikasikan pupuk organik sebanyak 10 ton/hektar pada lahan.

\section{Efisiensi}

Nilai efisiensi dari pengujian kinerja aplikator dapat diperoleh dari hasil persentase perbandingan antara nilai KLT dan nilai KLE yang diperoleh. Berdasarkan hasil perhitungan efisiensi, diperoleh bahwa nilai efisiensi pada perlakuan kecepatan $2,71 \mathrm{~km} / \mathrm{jam}$ yakni sebesar $74,74 \%$, pada kecepatan 3,38 km/jam yakni sebesar 73,4\% dan untuk perlakuan kecepatan 4,62 km/jam diperoleh nilai efisiensi sebesar 71,67\%. Adapun nilai efisiensi terbesar yang didapatkan adalah pada perlakuan kecepatan $2,71 \mathrm{~km} / \mathrm{jam}$ yaitu sebesar $74,74 \%$ sedangkan nilai efisiensi terendah didapatkan dari kecepatan 4,62 km/jam sebesar 71,67\%. Adapun perbandingan antara kecepatan dan efisiensi dapat dilihat pada Gambar 4.

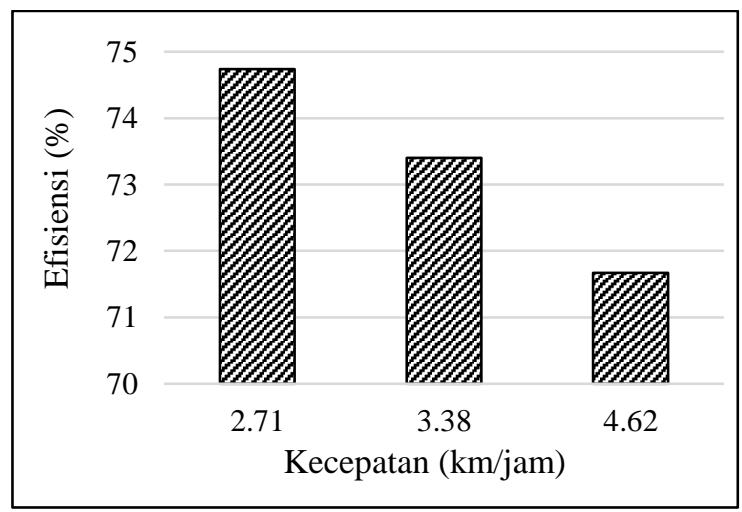

Gambar 4. Grafik Perbandingan Kecepatan dan Efisiensi Kinerja Aplikator

Pada Gambar 4, dapat dilihat bahwa nilai efisiesi kinerja aplikator semakin berkurang seiring dengan bertambahnya kecepatan. Sehingga waktu efektif pengoperasian aplikator bertambah meskipun dengan kecepatan pengoperasian aplikator yang cepat. Hal lain yang juga dapat mempengaruhi efisiensi antara lain kondisi lahan, kecepatan, dan kecakapan operator dalam mengoperasikan aplikator. Ini sejalan pernyataan Manik, et al. (2014), yang menyatakan bahwa kecepatan traktor dalam setiap pola pengolahan sangat mempengaruhi nilai efisiensi. 


\section{Keseragaman Penyebaran Pupuk Organik}

Keseragaman penyebaran pupuk organik pada lahan dilakukan dengan mengambil tiga sampel pupuk organik dengan panjang sampel $30 \mathrm{~cm}$ secara acak di setiap lintasan yang dilalui oleh aplikator yang kemudian ditimbang beratnya. Adapun keseragaman penyebaran pupuk ke lahan pada setiap kecepatan dapat dilihat pada Gambar 5.

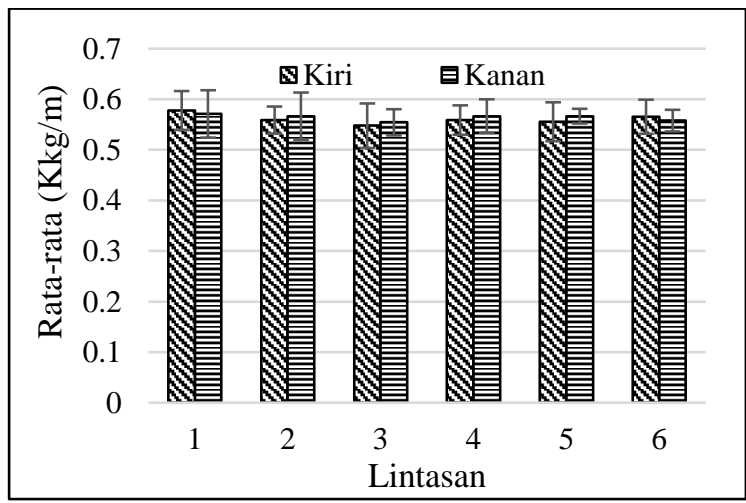

Gambar 5. Grafik Keseragaman Pupuk Organik yang Jatuh ke Lahan pada Kecepatan 2,71 km/jam

Berdasarkan Gambar 5, dapat diketahui bahwa pada kecepatan 2,71 $\mathrm{km} /$ jam rata-rata berat pupuk organik yang jatuh ke lahan pada berdasarkan sampel yang diambil yakni pada lintasan pertama pengeluaran kiri seberat $0,57 \mathrm{~kg} / \mathrm{m}$ dengan standar deviasi 0,0384 dan pengeluaran kanan seberat $0,571 \mathrm{~kg} / \mathrm{m}$ dengan standar deviasi 0,046. Pada lintasan kedua pengeluaran kiri seberat $0,558 \mathrm{~kg} / \mathrm{m}$ dengan standar deviasi 0,026 dan pengeluaran kanan seberat $0,56 \mathrm{~kg} / \mathrm{m}$ dengan standar deviasi 0,046. Pada lintasan ketiga pengeluaran kiri seberat $0,547 \mathrm{~kg} / \mathrm{m}$ dengan standar deviasi 0,044 dan pengeluaran kanan seberat $0,554 \mathrm{~kg} / \mathrm{m}$ dengan standar deviasi 0,025. Pada lintasan keempat pengeluaran kiri seberat $0,558 \mathrm{~kg} / \mathrm{m}$ dengan standar deviasi 0,029 dan pengeluaran kanan seberat $0,566 \mathrm{~kg} / \mathrm{m}$ dengan standar deviasi 0,033. Pada lintasan kelima pengeluaran kiri seberat $0,555 \mathrm{~kg} / \mathrm{m}$ dengan standar deviasi 0,038 dan pengeluaran kanan seberat $0,566 \mathrm{~kg} / \mathrm{m}$ dengan standar deviasi 0,014. Pada lintasan keenam pengeluaran kiri seberat $0,565 \mathrm{~kg} / \mathrm{m}$ dengan standar deviasi 0,033 dan pengeluaran kanan seberat $0,557 \mathrm{~kg} / \mathrm{m}$ dengan standar deviasi 0,021 .

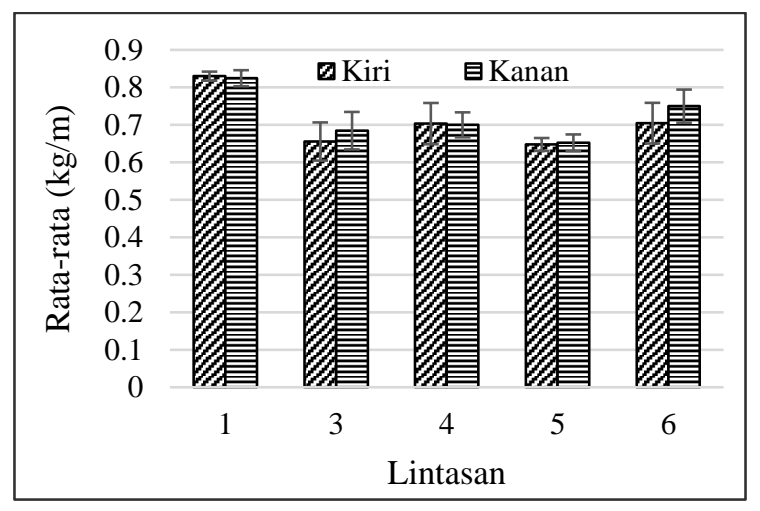

Gambar 6. Grafik Keseragaman Pupuk Organik yang Jatuh ke Lahan pada Kecepatan 3,38 km/jam

Gambar 6 menunjukkan bahwa untuk perlakuan kecepatan 3,36 km/jam, rata-rata berat pupuk organik yang jatuh ke lahan. Berdasarkan sampel yang diambil, pada lintasan pertama pengeluaran kiri seberat $0,83 \mathrm{~kg} / \mathrm{m}$ dengan standar deviasi 0,012 dan pengeluaran kanan seberat $0,824 \mathrm{~kg} / \mathrm{m}$ dengan standar deviasi 0,021. Pada lintasan kedua tidak ada sampel yang diambil disebabkan pupuk organik pada aplikator telah habis pada lintasan pertama dan baru diisi kembali pada lintasan ketiga. Pada lintasan ketiga pengeluaran kiri seberat $0,655 \mathrm{~kg} / \mathrm{m}$ dengan standar deviasi 0,05 dan pengeluaran kanan seberat $0,684 \mathrm{~kg} / \mathrm{m}$ dengan standar deviasi 0,05 . Pada lintasan keempat pengeluaran kiri seberat 0,703 $\mathrm{kg} / \mathrm{m}$ dengan standar deviasi 0,055 dan pengeluaran kanan seberat $0,7 \mathrm{~kg} / \mathrm{m}$ dengan standar deviasi 0,033. Pada lintasan kelima pengeluaran kiri seberat $0,647 \mathrm{~kg} / \mathrm{m}$ dengan standar deviasi 0,017 dan pengeluaran kanan seberat $0,652 \mathrm{~kg} / \mathrm{m}$ dengan standar deviasi 0,022. Pada lintasan keenam pengeluaran kiri seberat $0,704 \mathrm{~kg} / \mathrm{m}$ dengan standar deviasi 0,054 dan pengeluaran 
kanan seberat $0,75 \mathrm{~kg} / \mathrm{m}$ dengan standar deviasi 0,044 .

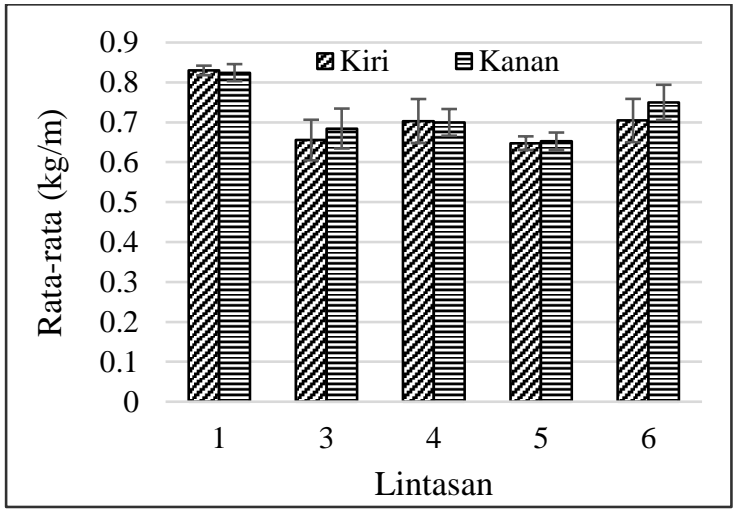

Gambar 7. Grafik Keseragaman Pupuk Organik yang Jatuh ke Lahan pada

Kecepatan 4,62 km/jam

Pada Gambar 7 terlihat bahwa untuk perlakuan kecepatan 4,64 km/jam, berat rata-rata pupuk organik yang jatuh ke lahan pada berdasarkan sampel yang diambil yakni pada lintasan pertama pengeluaran kiri seberat $0,744 \mathrm{~kg} / \mathrm{m}$ dengan standar deviasi 0,078 dan pengeluaran kanan seberat $0,744 \mathrm{~kg} / \mathrm{m} / \mathrm{m}$ dengan standar deviasi 0,058 . Pada lintasan kedua pengeluaran kiri seberat $0,851 \mathrm{~kg} / \mathrm{m} / \mathrm{m}$ dengan standar deviasi 0,045 dan pengeluaran kanan seberat $0,88 \mathrm{~kg} / \mathrm{m}$ dengan standar deviasi 0,027. Pada lintasan ketiga pengeluaran kiri seberat $0,758 \mathrm{~kg} / \mathrm{m}$ dengan standar deviasi 0,066 dan pengeluaran kanan seberat $0,757 \mathrm{~kg} / \mathrm{m}$ dengan standar deviasi 0,065. Pada lintasan keempat pengeluaran kiri seberat 0,727 $\mathrm{kg} / \mathrm{m}$ dengan standar deviasi 0,053 dan pengeluaran kanan seberat $0,722 \mathrm{~kg} / \mathrm{m}$ dengan standar deviasi 0,048. Pada lintasan kelima pengeluaran kiri seberat $0,844 \mathrm{~kg} / \mathrm{m}$ dengan standar deviasi 0,021 dan pengeluaran kanan seberat $0,827 \mathrm{~kg} / \mathrm{m}$ dengan standar deviasi 0,025 . Pada lintasan keenam pengeluaran kiri seberat $0,836 \mathrm{~kg} / \mathrm{m}$ dengan standar deviasi 0,055 dan pengeluaran kanan seberat $0,827 \mathrm{~kg} / \mathrm{m}$ dengan standar deviasi 0,063.

Data di atas menunjukkan bahwa ratarata besarnya pupuk yang jatuh ke lahan pada setiap kecepatan cenderung stabil.
Adapun kecepatan yang memiliki keseragaman tertinggi yakni pada kecepatan $2,71 \mathrm{~km} / \mathrm{jam}$ yang memiliki rata-rata berat pupuk yang jatuh ke tanah berkisar 0,547 $\mathrm{kg} / \mathrm{m}$ hingga $0,577 \mathrm{~kg} / \mathrm{m}$ dengan standar deviasi pada setiap lintasannya hanya 0,014 hingga 0,046. Hasil ini sejalan dengan penelitian yang dilakukan Kusnendi (2008), yang menunjukkan bahwa semakin besar standar deviasi, maka penyimpangan data dari rata-rata hitungnya akan semakin besar pula, yang berarti data mempuyai variabilitas yang tinggi (heterogen). Sebaliknya, semakin kecil standar deviasinya, maka penyimpangan data dari rata-rata hitungnya akan semakin rendah (variabilitas rendah).

\section{KESIMPULAN}

Penelitian ini menyimpulkan bahwa aplikator dengan kecepatan $2,71 \mathrm{~km} / \mathrm{jam}$ merupakan kecepatan yang terbaik. Efisiensi yang diperoleh pada kecepatan $2,71 \mathrm{~km} / \mathrm{jam}$ adalah $74,74 \%$. Hasil pengujian menunjukkan bahwa aplikator efisien untuk digunakan, selain menghemat jumlah tenaga kerja, waktu kerja yang dibutuhkan hanya 2-3 jam untuk lahan seluas $1 \mathrm{Ha}$. Perhitungan standar deviasi sampel pupuk yang jatuh ke lahan pada tiga kecepatan berbeda diperoleh nilai sebesar $0,033,0,036$, dan 0,05 yang menunjukkan bahwa jumlah pupuk yang jatuh ke lahan memiliki variasi yang kecil. Aplikator pupuk organik dengan tenaga tarik traktor 2 roda dapat beroperasi dengan baik pada lahan sawah tadah hujan.

\section{DAFTAR REFERENSI}

Dewanto, F. G., Londok, J. J. M. R., Tuturoong, R. A. V, \& Kaunang, W. B. (2013). Pengaruh Pemupukan Anorganik Dan Organik Terhadap Produksi Tanaman Jagung Sebagai Sumber Pakan. Zootek Journal, 32(5), 158-171. 
Hartono., Iqbal, \& Useng, D. (2018). Uji

Kinerja Aplikator Pupuk Organik Dan Pengaruh Bahan Organik Terhadap Sifat Fisik Tanah dan Pertumbuhan Tanaman Melon (Cucumis melo L.). Jurnal Agritechno. 11, 1 (Apr. 2018), 11(1), 59-66.

Iqbal, Achmad, M., \& Sapsal, M. T. (2019). Organic fertilizer applicators design for supporting rice production. IOP Conference Series: Earth and Environmental Science, 235(1). https://doi.org/10.1088/17551315/235/1/012038

Iqbal, I. (2014). Rancang Bangun Aplikator Kompos Untuk Tebu Lahan Kering. Jurnal Keteknikan Pertanian, 2(1).

Iqbal, Jafar, Y., \& Sapsal, T. (2021). Unjuk Kerja Rice Transplanter Sistem Jajar Legowo Tipe Crown Indo Jarwo Di Kabupaten Pinrang Sulawesi Selatan Performance Of Indo Jarwo Rice Transplanter Crown Type On Jajar Legowo System In Pinrang Regency South Sulawesi. Jurnal Teknik Pertanian Lampung, 10(1), 113-118. https://doi.org/ 1.v10.i1.113-118

Kusnendi. (2008). Model-Model Persamaan Struktural Satu dan Multigrup Sampai dengan LISREL. Alfabeta. Bandung.

Manik, A., Putra Munir, A., Saipul, D., \& Daulay, B. (2014). Pengaruh Kecepatan Pada Beberapa Model Implementasi Pengolahan Lahan Sawah (Influence on The Speed of Processing Multiple Implementation Models Wetland). In Keteknikan Pertanian J.Rekayasa Pangan dan Pert (Vol. 2, Issue 1).

Permatasari, S. (2014). Uji Kinerja Aplikator Kompos Pada Perkebunan Tebu Lahan Kering PG. Takalar.

Reijntjes, C., Haverkort, B., \& Bayer B. W. A. (1999). Pertanian Masa Depan: Pengantar Untuk Pertanian Berkelanjutan Dengan Input Luar Rendah. ILEILA (Terjemahan Y. Sukoco). Kanisius. Yogyakarta.

Salim, I. (2012). Kajian Alat dan Mesin Pengelolaan Serasah Tebu Pada Perkebunan Tebu Lahan Kering PG Takalar.

Sri, A.J., \& Soepartini, M. (1995). Pengelolaan pupuk pada sistem usaha tani lahan sawah. Makalah Apresiasi Metodologi Pengkajian Sistem Usatani Berbasis Padi Berwawasan Agribisnis. 